\author{
Martina Volarević \\ Sveučilište J. J. Strossmayera u Osijeku, Filozofski fakultet, Lorenza Jägera 9, HR-31000 Osijek \\ mzezelj@ffos.hr
}

\title{
Nesloboda slobode
}

\begin{abstract}
Sažetak
Cilj je rada ispitati doseg individualne slobode čovjeka u odnosu na njegovu tjelesnu nagonsku vezanost. Polazna je točka za ispitivanje Gehlenova biološka antropologija koja je ukazala na ljudsku slobodu instinktivnih pritisaka. Ljudska sloboda pokazuje se kao prilika za izgradnju vlastitoga svijeta djelovanjem. Sloboda djelovanja opterećuje čovjeka neprestanim donošenjem odluka. Rasterećenje od slobode djelovanja omogućava automatizam navike koji pruža čvrste obrasce nesvjesnih ponašanja. Društvene institucije svojim odgojem dodatno automatiziraju i time stabiliziraju djelovanje pojedinaca. Čovjek u svojem iz slobode proizvedenom svijetu generira drugostupanjsku samoproizvedenu neslobodu. Freud ukazuje na opresivni karakter kulture i civilizacije koja od pojedinca zahtijeva žrtvovanje nagonskog zadovoljenja radi kulturnog prosperiteta. Budući da nagonska represija raste s razvojem kulture, suvremeni čovjek postaje neurotičan jer ne može podnijeti stupanj odricanja koji od njega zahtijeva kultura.
\end{abstract}

\section{Ključne riječi}

Arnold Gehlen, Sigmund Freud, sublimacija, rasterećenje

\section{Uvod}

Tradicionalno filozofsko razmatranje ljudske slobode najčešće zatičemo u modusima ontološke slobode, društvene slobode i individualne slobode. Ontološka sloboda propituje mogućnost kauzaliteta na osnovi slobode u postojećem prirodnom determinizmu. Drugim riječima, je li moguća sloboda u svijetu u kojem se sve odvija po prirodnoj zakonitosti (Kant, 1956: 433438)? Društvena sloboda usmjerava se na problem sloboda pojedinca unutar građanskog društva u rasponu od Francuske revolucije, koja je zahtijevala slobodu, jednakost i bratstvo u Deklaraciji o pravima čovjeka i građanina, do Opće deklaracije o pravima čovjeka Ujedinjenih naroda iz 1948. godine. Zajedničko je svim tim oblicima određenja sloboda pojedinca u društvu to što određuju prava pojedinca u koja zakonodavne vladajuće strukture ne smiju intervenirati, poput prava na vlasništvo, život, slobodu vjeroispovijesti i slobodno izražavanje. Problem individualne slobode ponajviše je okupirao egzistencijalnu filozofiju sredine dvadesetog stoljeća koja propituje mogućnost autentičnog samoodređenja pojedinca unutar suvremenog društva. Navedene moduse promišljanja slobode ne treba shvatiti kao alternativne puteve mišljenja, već kao načine iznošenja u prednji plan određenih aspekata problema slobode. Drugim riječima, sve opcije promišljanja slobode imaju ishodište u mišljenju slobode individuuma kojeg samo zahvaćaju iz drugačijeg kuta.

Ovaj rad odmiče se od prethodno navedenih puteva mišljenja slobode propitujući biološku slobodu čovjeka - slobodu čovjeka od nagonskih pritisaka njegova tijela te prednosti i nedostatke nagonske nevezanosti. Iako čovjeka 
razumijeva kao sintezu duše i tijela, filozofska je tradicija sklona dati primat duši u odnosu na tijelo. Ona određuje čovjeka kao jedino duhovno biće koje je u stanju umom kontrolirati nagone svoga tijela. Jedini iskorak u suprotnom smjeru unutar filozofske tradicije zatičemo kod Nietzschea, koji suprotstavljanjem apolonijskih i dionizijskih elemenata daje određeno priznanje nagonskom i tjelesnom. U ovom je radu sučeljeno Gehlenovo izlaganje ljudske slobode od nagona i načina pomoću kojih čovjek nadilazi taj »nedostatak« te Freudovo koje razumijeva čovjeka kao nagonsko biće koje - iako raspolaže s mogućnošću odgađanja njihova zadovoljenja - na koncu nagonima ipak mora pružiti zadovoljenje.

\section{Gehlenovo određenje nagonske nevezanosti čovjeka}

Filozofska antropologija suglasna je u tome da čovjeku pripada poseban položaj unutar živog svijeta jer on je biće čiju bit prožima dvoznačnost u smislu dvoznačnosti tjelesnog i umstvenog. S jedne strane, u skladu s prirodoznanstvenim određenjem koje se usmjerava na tjelesni aspekt ljudskoga opstojanja, on je ishod razvoja životinjskih vrsta kao najrazvijeniji kralješnjak i sisavac. Prirodoznanstveni pristup, smatrajući čovjeka najrazvijenijom životinjskom vrstom, proklamira postojanje samo kvantitativne razlike između čovjeka i ostalih životinjskih vrsta, što znači da čovjek samo raspolaže sa složenijim stupnjem sposobnosti koje su bile nazočne već u životinjskom svijetu. Za razliku od prirodoznanstvenog pristupa, filozofska tradicija apostrofira postojanje kvalitativne razlike između čovjeka i ostalih živih bića, određujući čovjeka kao jedino biće koje raspolaže višim umstvenim sposobnostima (usp. Scheler, 1991: 11).

Instinkt (der Instinkt), koji je za Schelera pokretač cjeline životinjskog djelovanja, određen je kao svako činjenje koje pridonosi opstanku jedinke i vrste. Instinktivno je činjenje urođeno i nasljedno kao unaprijed zgotovljeno specifično ponašanje koje se ponavlja na ritmičan način. Kao takav, instinkt pruža automatske i apsolutno ispravne reakcije na specifične osjetilne percepcije iz okoline koje su vrsno tipične i relevantne za opstanak. Automatizam primjerene reakcije znači da je u instinktu dano urođeno nerazdvojivo jedinstvo znanja i radnje, znanja koje ne zahtijeva promišljanje posredovano predodžbenim kompleksom. ${ }^{1}$ Iako se činjenje u životinjskom svijetu ne iscrpljuje onim instinktivnim, instinktivno stoji u temelju svakog životinjskog djelovanja, pružajući motiv za više sposobnosti, poput asocijativnog pamćenja i praktične inteligencije. Motivacija pri životinjskom djelanju ne nadilazi zadovoljenje temeljnih nagona: spolnog instinkta i instinkta za samoodržanjem. Učenje ili asocijativno pamćenje utemeljeno je na asocijativnoj zakonitosti po kojoj predodžbeni kompleks pokušava nadopuniti nedostajuće članove utoliko ukoliko nastane osjetilna percepcija jednog ili više članova. ${ }^{2}$ Predodžbeni kompleks obuhvaća cjelinu predodžbi koje se usavršavaju i nadopunjavaju učenjem, a koje su potrebne za postizanje određene radnje koja zadovoljava nagonski cilj. Sposobnost učenja nije jednako zastupljena kod svih životinjskih vrsta te stoga treba razlikovati životinje na nižem stupnju razvoja koje karakteriziraju zatvoreni instinktivni kompleksi od životinja na višem stupnju razvoja koje karakterizira disocijacija instinktivnih kompleksa. Zatvoreni instinktivni kompleksi nerastavljivi su sljedovi reakcija na određeni opažaj iz okoline, a za razliku od njih, disocirani instinktivni kompleksi rastavljanje su sljedova reakcija na mnoštvo djelomičnih kretnji koje jedinka može slobodno kombi- 
nirati te tako proširiti njihovu primjenu. Za razliku od učenja, gdje napredak u ostvarenju instinktivnog cilja nastupa kroz postepeno usavršavanje radnje, kod praktične inteligencije ostvarenje cilja nezavisno je od ponavljanja te ona osvaja ili promašuje cilj pri prvom pokušaju. Produktivno je mišljenje praktične inteligencije poput asocijativnog pamćenja posredovano predodžbenim kompleksom, no kod njega je nadopunjena reprodukcija predodžbenog kompleksa na temelju prethodnog iskustva anticipacijom ishoda radnje na temelju novonastalog uvida u vrijednost i smislenost stanja stvari u okolini. Drugim riječima, pri djelovanju praktične inteligencije stvari koje su dio ravnodušne okoline dobivaju vrijednost alata za postizanje praktičnog cilja. Osim asocijativnog pamćenja i praktične inteligencije, viši razredi sisavaca imaju i sposobnost izbora, što znači da su sposobni izbjegavati vremenski bliže, manje prednosti da bi zahvatili veće, vremenski udaljenije. Sve izloženo pokazuje da se životinje ne mogu poistovjetiti s instinktivnim mehanizmima, da raspolažu sa sposobnostima koje, iako ostaju instinktivno motivirane, nadilaze puku instinktivnu danost (usp. Scheler, 1991: 18-36).

Za razliku od životinja, čovjeku njegova tjelesno-instinktivna uvjetovanost nije dovoljna za opstanak. Iako predstavlja dovršetak evolucijskog razvoja životinjskih vrsta, čovjek je bitno manjkavog instinktivnoga ustrojstva. Ljudski su instinkti zakržljali te kod čovjeka izostaje automatizam znanja i radnje karakterističan za instinktivnu sinapsu, preciznije automatizam je nazočan samo u simpatičkom i parasimpatičkom autonomnom živčanom sustavu koji su zaslužni za nesvjesne radnje poput disanja, treptanja i sl. Budući da je za automatsku instinktivnu reakciju potreban specifični podražaj iz okoline, čovjekova je instinktivna zakržljalost usko vezana uz njegovu nespecijaliziranost. Čovjeku nedostaje bilo kakva visokospecijalizirana morfološka prilagodba odgovarajuća za određeno stanište. Morfološke prilagodbe, među ostalim, omogućavaju primanje senzomotornih podražaja iz okoline koji aktiviraju instinktivni mehanizam. Morfološki, čovjek je, u suprotnosti spram ostalih životinja, manjkavo biće koje bi unutar bilo kojeg prirodnog staništa bilo iskorijenjeno. Tome je tako jer se razvoj životinjskog svijeta kreće u smjeru visoko specijaliziranih morfoloških formi za precizno određena staništa.

»Zašto nije izumrla tako loše prilagođena vrsta kao što je izumrlo stotine drugih? Kako je bilo moguće da se ovo gotovo na smrt osuđeno biće, ova bolesna, zaostala, bolna životinja, s osnovnim držanjem bojažljivog samoogrtanja, samozaštite svojih loše prilagođenih, pretjerano povredljivih organa, spasi u 'principu čovječnosti', a time u civilizaciji i kulturi? (Scheler, 1991: 61)

Čovjek siromašnu instinktivnu danost svoje egzistencije nadomješta nizom specifično ljudskih sposobnosti. Djelovanje i jezik Gehlen ističe kao najzna-

1

»Znanje» koje je nagonsko te se prenosi trans-generacijski u životinjskoj vrsti, npr. mačkino znanje da zakopa izmet i ostatke hrane. Dakle, ono nije ishod ni induktivnog ni deduktivnog zaključivanja, a ne može se poistovjetiti ni s intuicijom koja je također posljedica spontano nastalog ispravnog uvida na temelju predodžbenog kompleksa.

Klasično uvjetovanje Pavlovljeva uvjetnoga refleksa primjer je asocijativnog pamćenja jer je Pavlov ponavljanjem uspio nadopuniti asocijativni predodžbeni sklop neuvjetovanim podražajem. Naime, Pavlov u svojem eksperimentu sa psima polazi od nagonski zadanog uvjetovanog podražaja (hrana) i reakcije (slinjenja) te ih proširuje neuvjetovanim podražajem pomoću zvuka metronoma, koji psi čuju prije no što im je dana hrana. Nakon što su psi usvojili neuvjetovani podražaj, koji je vezan u predodžbeni kompleks, i u slučaju kada izostaje uvjetovani podražaj reproducira se nagonska reakcija (usp. Saunders, 2006: 44-54). 
čajnije temeljne fenomene ljudskog opstojanja. ${ }^{3} \mathrm{U}$ izlaganju fenomena ljudske egzistencije, djelovanje $\mathrm{e}^{4}$ zauzima središnje mjesto jer je ono temeljni način na koji čovjek nadoknađuje nagonske i morfološke nedostatke. On svojim radom i djelovanjem preobražava prirodu oko sebe u kulturu te time sebi osigurava opstanak. Novonastala kultura služi čovjekovu životu te omogućava da on ostvari svoje mogućnosti.

»Već ovdje leži zadatak fizičke i po život važne prodornosti: čovjek se mora vlastitim sredstvima i samosvojno rasteretiti, tj. oskudne uvjete svoje egzistencije samovoljno preraditi u šansu svoga životnog održanja.« (Gehlen, 1978: 37)

Ljudsko djelovanje karakteriziraju komunikativne kretnje, što prvenstveno znači da osjetilno iskustvo stvari izrasta iz instinktivno rasterećenog ophođenja s njima. Ophođenje sa stvarima svojevrsni je dijalog jer čovjek svoje kretnje razvija u odnosu sa stvarima u djelatnosti koje nisu vođene zadovoljenjem potreba. Rasterećena i nagonske prisile lišena komunikativna kretnja usmjerava se na stvar uzimajući u obzir reakciju same stvari na djelovanje te $u$ istom mahu povratno prima informaciju o svom djelovanju na stvar od strane stvari (Gehlen, 1978: 176, 235-236). Fantazija kretnje usmjerena je prema izgradnji temeljnih faza kretnje. Temeljne faze čine zglobove djelovanja iz kojih se može raspolagati kretnjom. To znači da je čovjek u stanju kretnje shvatiti kao faze cjeline, anticipirajući krajnji ishod. U svakom zglobnom mjestu on može prekinuti kretnju te započeti sadržajno nevezani niz kretnji; isto tako on može kombinirati faze različitih kretnji. Sve navedeno ukazuje na beskonačne mogućnosti ljudskog djelovanja. Fantazija kretnje u konačnici pruža skicu narednih mogućih faza djelovanja te mogućih varijacija koje su otvorene u određenim zglobovima kretnje. Dakle, svako ljudsko djelovanje uvijek je određeno poviješću svojih reakcija koje nastaju kroz sabiranje pasivne uobrazilje. ${ }^{5}$ Funkcija je pasivne uobrazilje rasterećivanje ljudskog djelovanja jer čovjek na temelju sabranih prethodnih djelovanja raspolaže automatskim adekvatnim odgovorom na buduća ista ili slična djelovanja. Te pasivne slike sjećanja mogu se aktivirati i suodrediti buduća intendirana djelovanja koja nisu puko ponavljanje prethodno sabranih djelovanja (usp. Gehlen, 1978: 253).

Simbol $^{6}$ je potpuno apstraktan znak nastao stavljanjem u zagradu svih ostalih osjetilnih karakteristika stvari, dakle, on nastaje samo ondje gdje se može odvojiti od označenog i nikad ne znači ništa drugo osim sebe samog. Pomoću simbola svaka iskustvena stvar u sebi sadrži naznaku svojih svojstava i mogućnosti primjene tih svojstava u iskustvu. Ljudski je svijet sazdan od polja simbola koji mu omogućavaju brzu orijentaciju koja rasterećuje ljudsko djelovanje jer on ne mora ispitivati svojstva stvari u svakoj pojedinačnoj situaciji. Čovjek rijetko dovodi u pitanje simboličku danost stvari, on ne sumnja u predodžbenu danost simboličkih nagovještaja, što u konačnici znači da se čovjek samo minimalno ophodi sa stvarima i znatno više s njihovim predodžbama (usp. Gehlen, 1978: 222, 214-215).

$»$ Rasterećenje je totalno: čovjek se kreće u naučenim, varijabilno primjenljivim, neiznuđenim kretnjama unutar prostora nagovještaja intimnih tamo postavljenih stvari, uz to pod principijelnom nezavisnošću svog opažajnog života i života kretnje od svojih poriva.« (Gehlen, 1978: 218)

Fantazija kretnje i simbol krajnje uspješno razrješavaju potrebu za izravnim odnosom spram svijeta. Ljudsko je odnošenje uglavnom reducirano na pregledne nagovještaje upotrebe. U tom svijetu stvari su poznate - čovjek ih savladava letimičnim pogledom i dostupne - i kada se ljudska djelatnost povlači s određenih stvari one ostaju dostupne za primjenu. Tako čovjek stječe 
neutralnu intimnost svijeta $u$ kojem u svakom trenutku može djelovati, automatiziranim samoizgrađenim radnjama koje sa sigurnošću vode do uspjeha (Gehlen, 1978: 132, 177).

Jezik samo na savršeniji način ponavlja ono što je unutar ljudske egzistencije postignuto djelovanjem pomoću simbola. ${ }^{7}$ U glasovnom djelovanju čovjek prima osjetilno povratni doživljaj koji je usavršen jer je »'razmaterijaliziran',

Za razliku od Gehlena, koji u posebnostima ljudskog opstojanja vidi prilagodbu na nespecijaliziranost, Scheler smatra da postoji kvalitativna razlika između čovjeka i ostalih živih bića. Čovjek je jedino duhovno biće, a pod duhom on smatra um, mišljenje ideja, zrenje prafenomena te određenu vrstu emocionalnih i volitivnih akata (usp. Scheler, 1991: 38).

4

Za postavljanje djelovanja kao temeljnog fenomena ljudskog opstojanja Gehlen je bio nadahnut Fichteovim određenjem djelovanja (Handeln, Handlung), preciznije, lijevo orijentiranim interpretacijama Fichteova određenja. Bošnjakovo određenje djelovanja je na tom tragu jer on pri tumačenju Fichteove filozofije apostrofira djelovanje. Fichte tvrdi da je čovjeku po njegovu umu dano slobodno djelovanje koje $\mathrm{u}$ prirodi ostaje podređeno nužnosti. Za njega 'Ja jesam' znači stvaralačku djelatnost po kojoj Ja postaje svjesno razlike između sebe i ostalih stvari (ne-Ja), stvari koje mijenja svojim radom $i$ time proširuje svoj svijet. Čovjekovo djelovanje unosi red i zakonitost $\mathrm{u}$ beskonačnu različitost postojećih stvari koje ne samo da stavlja u nužni red nego im i daje vlastiti red. Svojim radom čovjek treba biti usmjeren prema drugim ljudima te je stoga čovječanstvo zajednica u koju se ljudi uključuju da bi svojim radom sudjelovali u razvoju ljudskog roda (usp. Bošnjak, 1993: 60-67).

Navedeno određenje pasivne uobrazilje Gehlen baštini iz Kantova razmatranja reproduktivne uobrazilje u Kritici čistog uma. Za Kanta, sinteza reprodukcije u uobrazilji empirijski je zakon prema kojem se združuju predodžbe koje učestalo slijede $\mathrm{u}$ iskustvu. Ta vrsta zajedništva omogućava da svijest spontano prelazi s jedne na drugu predodžbu bez osjetilne danosti. Od nje uvijek treba razlikovati produktivnu sintezu uobrazilje koja je transcendentalna moć razuma. Produktivna uobrazilja ona je koja se odnosi isključivo na sintezu raznolikog a priori kojoj u temelju stoji transcendentalna apercepcija - identitet sebe samog kod svih mogućih predodžbi (usp. Kant, 1956: 145a-149a, 160a-174a).

Cassirer razumijeva simboličnu funkciju kao opću teoriju smatrajući da je svaka predodžba simbolična - predodžbe su dane opažanjem, dok su simboli sačinjeni umom od predodžbi iskustva. Preciznije, svijest uzima dani sadržaj te poznačava univerzalno značenje koje se nalazi u predodžbi. Takva je simbolična predodžba univerzalna jer pripada samom karakteru ljudske svijesti, ukazujući na simbol kao puninu značenja uspostavljenog cjelinom ljudskog iskustva. Navedeno ga vodi $\mathrm{k}$ stavu da je potrebno pronaći prirodni simbolizam za predodžbe svijesti utoliko ukoliko želimo shvatiti proizvoljne simbole koje svijest stvara u jeziku umjetnosti i mitu (usp. Cassirer, 1980: 73-93). Nešto drugačije utemeljenje univerzalne simbolične funkcije daje i Lévi-Strauss. On polazi od proučavanja života primitivnih plemenskih zajednica, tj. njihova temeljna zakona koji regulira pravila orođivanja unutar zajednice. Imperativna egzogamija ukazuje na postojanje sveobuhvatne, potpuno drugačije funkcije u ljudskom poretku budući da ne postoje prirodni razlozi zašto bi se dala prednost egzogamiji u odnosu na endogamiju. Nova je funkcija u ljudskom poretku simbolička funkcija koja u potpunosti prožima ljudski poredak u svakom trenutku i na svakom stadiju njegova postojanja. Proučavanje simboličke funkcije treba zasnovati na analizi elementarnih zajednica jer se kod njih najjasnije pokazuje moć simboličke funkcije. U njima pravila saveza razmjene žena dio su iznimno bogate i luksuzne mreže prednosti i zabrana, upozorenja, naredbi, olakšavanja (usp. Lévi-Strauss, 1969: 3-12).

Plessner u tekstu »Današnji interes filozofije za jezik« u potpunosti ignorira Gehlenova izvođenja te kao dominantu vidi sraz fenomenološkog i lingvističkog razumijevanja jezika. Lingvistička analiza u Wittgensteinovu ključu naglasak stavlja na odstranjivanje jezičnih nejasnoća da bi se postiglo slaganje s jezikom svakodnevnice. Fenomenologija se zalaže za povratak iskonu koji će razotkriti temelj te će se time riječ pokazati kao svitanje bivstvujućeg u bitku. Navedene struje kreću se u dijametralno suprotnim smjerovima: lingvistička analiza prema podruštvljenju, a fenomenologija prema osamljenju. Fenomenološko iskustvo riječi ne ostvaruje se u društvenom horizontu jer iskustvo je bivstvujućeg u njegovu bitku individualno iskustvo pojedinca (Plessner, 1985: 384-392). 
najviše rasterećeni i bestrudni način kojim sebi činimo intimnim i raspoloživim svijet preko samopostavljenih simbola« (Gehlen, 1978: 215, 233). Intencija na stvar slijedi kroz glasove jezika koji su samoproizvedeni glasovni simboli. Navedeni karakter jezičnog djelovanja proizlazi iz prirode samog glasa. Glas se zbog svoje proizvoljne ponovljivosti može odvojiti od prvobitne situacije i potrebe kojoj je pripadao te time čovjeku omogućava pristup stvari samoj. Imenovanje stvari u jezičnoj komunikaciji ima za posljedicu intimiziranje svijeta stvari koje su ujedno prepoznate i dokinute u njihovoj jezičnoj danosti. Posljedica je nove zbiljnosti stvari u jezičnoj danosti riječi da djelovanje više ne mora intervenirati u zbiljnosti jer sama jezična danost odgovara stvarima te više ne postoji potreba za djelovanjem komunikativnom kretnjom. Zato je za Gehlena jezik prvenstveno vid djelovanja koji je u stanju nadomjestiti djelovanje komunikativne kretnje. Jezik je kao djelovanje samodovoljan jer se pomoću njega može ostvariti intencija na stvari, on sam bez uplitanja komunikativnih kretnji može uspostaviti novo stanje stvari (Gehlen, 1978: 240-244).

»Ljudske kretnje, općenito, slične su jeziku utoliko što su isto tako povratno osjetilne kretnje (viđene, osjećane, opipane), utoliko što su, nadalje, također komunikativne i, treće, simbolične i varijabilne. Zato jezični glas može, nastajući unutar njih, istupiti za njih [...] jednako važno može jezični glas istupiti za kretnju, ili je smijeniti ili početi [...].«(Gehlen, 1978: 234)

Izloženo ukazuje na rasterećujuću narav jezika; na opažajnoj strani on rasterećuje od osjetilnog pritiska koji može stvoriti požudno-instinktivni interes za stvar. Zbiljnost onakva kakva je dana u jezičnoj komunikaciji instinktivno je neutralna intencija na stvari, intencija koja uvijek opstoji u odstojanju spram stvari same u samo simboličkoj danosti riječi. Jezik kao djelovanje rasterećuje jer ne samo da ima moć činjenja nego se u njemu razvija i posebna dimenzija duhovnog djelovanja koje se u potpunosti ostvaruje u jezičnoj simboličkoj zbiljnosti (usp. Gehlen, 1978: 250-268).

Za opstanak čovjeka, koji je nespecijalizirano biće, od presudnog je značaja to što postoji procijep između potrebe i njezina ispunjenja, jer on planiranim i stvari primjerenim djelovanjem stvara ono što mu je potrebno za opstanak. Za nastanak procijepa nužno je da čovjek raspolaže mogućnošću kočenja instinkata koja mu omogućava upravljanje vlastitim djelovanjem. Sposobnost kočenja znači da čovjek raspolaže slobodom odluke o tome hoće li dopustiti ili zabraniti zadovoljenje određenog instinkta. U protivnom, čovjek bi poput ostatka životinjskog svijeta zadovoljavao potrebe pomoću automatizma instinktivnog. Budući da ljudsko zadovoljavanje potreba nije vođeno instinktivnim automatizmom, on sam određuje sadržaje svojih potreba i poriva na temelju slika iskustva. Slike iskustva pounutrene su predodžbe vanjskog osjetila koja oblikuju ljudske želje. Čovjekove potrebe, instinkti i interesi postoje samo u formi predodžbi želja na temelju slika prethodnog iskustva (usp. Gehlen, 1978: 341).

Čovjekovo djelovanje nikad nije usmjereno prema zadovoljavanju trenutačnih potreba jer kod čovjeka zadovoljenje i najelementarnijih potreba zahtijeva dalekosežne intervencije u svijet djelovanjem. On predviđa svoje buduće potrebe te u skladu s njima projektira svoje djelovanje u dugoročnim djelatnostima koje odgovaraju njegovim trajnim zadacima. Zato je kod čovjeka nemoguće razlikovati neposredna djelovanja uvjetovana primarnim potrebama i posredovana djelovanja vođena udaljenijim svrhama koja zadovoljavaju sekundarne potrebe. Sve su ljudske potrebe »više« potrebe jer čovjek je u 
stanju tek na temelju u svojem djelovanju spoznatih i ovladanih stanja stvari zadovoljiti primarne potrebe (usp. Gehlen, 1978: 332-338).

Čovjekovi su trajni interesi učvršćeni pomoću navike koja rasterećuje čovjeka od višestrukog pronalaženja motivacije i ponavljajuće izgradnje putanje djelovanja na temelju spoznaje stanja stvari u svijetu. Navikom je ostvaren drugostupanjski automatizam instinktivnog jer pri naviknutom ponašanju čovjek djeluje automatski na opažaj stvari u svijetu, dakle, postoji svojevrsna uspostava izvanjskog impulsa i instinkta. Tvorba motiva učvršćena je pomoću predmeta izvanjskog svijeta koji kao simboli imaju izazivajući učinak i tako daju stabilnost i jamstvo trajnosti ljudskom naviknutom djelovanju. Navika ne samo da rasterećuje nego i stabilizira određene forme djelovanja jer automatizam reakcije kod naviknutog djelovanja jamči postojanost forme koju se više ne propituje. Tako automatizirano djelovanje čini temelj za daljnja varijabilna djelovanja na temelju trajnih interesa (usp. Gehlen, 1994: 22-25, 66).

»... ne-logički načini ponašanja svakodnevnog »širokog« iskustva, u kojem kvaziinstinktivne izvjesnosti, navike i nefiltrirane uvjerenja igraju tako veliku ulogu, isključuju po svojoj prirodi stvarnosno - eksperimentalno postavljanje naspram istog objekta.« (Gehlen, 1978: 310)

Na taj način formiraju se i razvijaju ljudski »instinkti« te je zbog toga kod čovjeka jako teško postaviti razdjelnicu između instinkta i navike. Tu razliku postavlja svaki pojedinac ponaosob kad modificira svoje potrebe u trajne interese za djelovanja strogo određena prema njegovim afinitetima, a koja se tiču strogo određenih činjenica stanja stvari u svijetu. Posebnost čovjekova opstojanja jest u tome što je u stanju uzdići do potrebe najspecijaliziranija djelovanja te pronaći u njima ispunjenje i zadovoljenje (usp. Gehlen, 1978: 334). Navike, trajni i površni interesi razotkrivaju njihova nositelja te je čovjekovo biće određeno u njegovim navikom uspostavljenim instinktima te poretkom njegovih interesa i potreba utemeljenih na iskustvenim predodžbama željenog. Čovjekova unutrašnjost nije samostalno postala izolirana jezgra njegova bića, već je porozno i osmotično središte ispunjeno političkim, kulturalnim i svakodnevnim sadržajima njegova svijeta.

Tako je uspostavljen ljudski karakter ${ }^{8}$ građa djelovanja kao sklop držanja nastao iz prerađenih instinkata koji su se orijentirali među sobom i prema svijetu te na taj način uspostavili relativno čvrstu strukturu. Čvrsta struktura utjelovljenog poretka djelovanja jamči pouzdanost i rasterećujući automatizam ritmičnih samoizvršenja. Karakter kao skup stabiliziranih navika i držanja koji stvara trajne paradigme ponašanja uvjetovane trajnim poretkom vrijednosnih držanja rezultat je društvenog odgoja (usp. Gehlen, 1978: 375, 380).

Za društveni odgoj, koji se u karakteru pojedinca manifestira kao ispunjenost njegovih navika, interesa, potreba i želja kulturnim i političkim sadržajima, zaslužne su institucije. Temeljna je zadaća institucija društva stabilizacija plastičnog i nestabilnog djelovanja pojedinaca u pojednostavljene društveno propisane obrasce djelovanja. Institucije uspostavljaju prividno instinktivne navike, djelovanja, mišljenja, osjećanja i vrednovanja koja pružaju pouz-

8

Utjecaj društva na određenje karaktera pojedinca razmatra i Plessner u članku »Elementi ljudskog ponašanja «, u kojem tvrdi da ljudski personalitet nastaje kroz socijalni sklop koji nas inkorporira imenovanjem kojem je dodijeljena određena uloga i status. Čovjek kroz svoju ulogu ostvaruje svoj status u društvu, no ona je ujedno i način na koji od očiju javnosti ostaje skrivena njegova privatna egzistencija On je, dakle, upućen na socijalnu ulogu, no ona ne iscrpljuje određenje njegova karaktera (usp. Plessner, 1994: 109-117). 
danost i predvidljivost ljudskog djelovanja. Navedeno znači da sve kulture životno nužno djelovanje pojednostavljuju i stereotipiziraju u sustave stabiliziranih navika. Pojednostavljen proces djelovanja kroz selekciju načina ponašanja jamči trajanje i vremensku otpornost kulturnih tvorbi. Stabilizirana djelovanja koja su postala osamostaljene navike uspostavljaju porast slobode jer institucije osamostaljenjem navika ostvaruju stanje permanentne ispunjenosti primarnih potreba koje time prestaju pružati pobuđujući moment. Pobuđujući moment premješta se u predmet te interes za sam predmet postaje primarna svrha djelovanja. Iz takve stabilizacije navika institucijama slijedi uključivanje novih motivskih skupina i svrha koje se osamostaljuju kao mreža odnosa elemenata institucija. Novonastale motivske skupine i primarni interes za predmet vezani su uz nastanak podjele rada u društvu jer tek kad zadovoljenje primarnih potreba postane pozadinsko ispunjenje, a interes za predmet postane prioritet, moguće je uspostaviti podjelu rada. S druge strane, samo one institucije koje su izrasle iz formalizacije i dodatnog pojednostavljenja običajno postojeće podloge naviknutog dugoročno će ostvariti trajnost. Isto tako, institucije koje temelje svoj legalitet na imperativom nametnutim zakonima, koje vještački propisanim jezično izrečenim aktom izazivaju i nastavljaju radnju kad ne postoji temelj običajnog, nisu u stanju dugoročno nametnuti svoje imperative. Propadanje institucija uvijek se očituje u društvu kao nesigurnost i nezaštićenost ponašanja od suviška podražaja (usp. Gehlen, 1994: 19, 24, 28).

Moderni subjektivizam ${ }^{9}$ koji dominira kulturama modernog doba ugrožava opstanak institucija, a time i automatizma naviknutog i rasterećujućeg običajnog. Budući da pojedinac inzistira na vlastitom određenju ideala i vrijednosti, odbacujući običajno postojeće navike i norme ponašanja, dolazi do propadanja društva. Tome pridonosi i pohlepa čovjeka modernog doba spram preobilja doživljajnog te poniranja u svoju autentičnu unutrašnjost.

»... u mnoštvu posebnih klima (priroda), koje se uzajamno reflektiraju i u tom senzibiliziraju svoju dušu koja je ostala bez zaštite od nadražaja i više se ne štiti iz tvrđave respektiranih navika - taj svijet daje, sadržaje za, u stvari, reprezentativne forme umjetnosti zapadnog svijeta: za psihološki roman.«(Gehlen, 1978: 380)

\section{Nesloboda kulturne slobode}

Za razliku od Gehlena, koji u društvenim institucijama pronalazi vrijednosno pozitivne stabilizatore ljudskog ponašanja koji u konačnici navikom rasterećuju te omogućavaju porast ljudske slobode u vidu nevezanosti za zadovoljenje instinkata, Freud u kulturnim institucijama vidi prvenstveno forme bespotrebne represije. U tekstu Nelagoda $u$ kulturi on ističe da čovjek ne treba prihvatiti socijalni izvor patnje jer su kulturne institucije ljudsko djelo nastalo sa svrhom dobrobiti i zaštite ljudi. U skladu s navedenim, Freud određuje kulturu kao:

»... 'kultura' označava cjelokupni zbir postignuća i ustanova u kojima se naš život razlikuje od života naših životinjskih predaka i koje služe dvjema svrhama: zaštiti čovjeka od prirode i uređenju odnosa među ljudima.« (Freud, 1955: 448)

Kulturi Freud daje priznanje kada je riječ o zaštiti čovjeka od prirode pomoću znanosti i tehnike, no pritom smatra da su zasluge tih civilizacijskih dostignuća minimalne. Istina jest da je tehnika upotrebom alata izgradila ljudski svijet koji je omogućio ljudsko samoodržanje. Unatoč svim doprinosima, tehnička 
civilizacijska dostignuća nisu bila u stanju pružiti članovima društva ispunjeniju egzistenciju, već samo lagodniji život. Za Freuda, osnovni je kriterij ispunjenja egzistencije povećanje obima zadovoljstva i sreće, gdje civilizacija zapadnog kruga nije ostvarila vidljive rezultate (Freud, 1955: 446).

Osim znanstvenih i tehničkih dostignuća, kulturi se pripisuje i sklonost visokoj valorizaciji ostalih intelektualnih djelatnosti, posebice onih koje ne služe samoodržanju. Među takvim samosvršnim djelatnostima posebno mjesto zauzimaju umjetničkih postignuća. Od čovjeka, ukoliko nije u stanju vlastitim umijećem proizvoditi umjetnička djela, u kulturi se očekuje da utoliko cijeni i uživa u prirodnim i sačinjenim lijepim predmetima. Čovjekova intelektualna znatiželja ne smije se iscrpiti u estetskim užicima, već on u jednakoj mjeri treba biti zainteresiran i za mišljenje ideja religioznih sustava te filozofsku spekulaciju.

Čovjek je u svojoj osnovi nagonsko biće te, da bi se podvrgnuo pod kulturne zahtjeve i ideale, mora žrtvovati dio vlastitih nagonskih zadovoljenja. On pristaje na to jer je $\mathrm{u}$ ishodišno pretpostavljenom prirodnom stanju ${ }^{10} \mathrm{svu}$ raspoloživu nagonsku energiju trošio na opstanak. U prirodnom stanju pojedinac je bio prepušten volji najjačeg koji je podredio zbiljnost zadovoljenju svojih nagona i interesa. Kultura nameće ograničenja apsolutnoj slobodi volje jačeg prirodnog stanja uvođenjem legislativne regulative libidoznim i agresivnim nagonskim tendencijama. Dakle, pojedinac ulaskom u kulturu gubi apsolutnu slobodu kojom je raspolagao samo u latenciji jer je bio podvrgnut volji jačeg, a dobiva jamstvo pravednosti i jednakosti da nitko neće biti izuzet iz novonastalog zakona.

»Suština leži u ograničenju mogućnosti zadovoljenja članova zajednice. Pojedinac nije poznavao takve ograde. Slijedeći zahtjev kulture je stoga pravda, to će reći osiguranje da jednom stvoren poredak neće ponovo biti skršen u korist pojedinca.« (Freud, 1955: 455)

Trenutkom nastanka kulture možemo smatrati prvi pokušaj uređenja društvenih odnosa koji nastupa kada se udruži većina koja zajedničkim naporima svlada najjačeg. Freud na temelju analize primitivnih zajednica zaključuje da je prva kultura totemistička kultura. Prelazak od prirodnog stanja volje jačeg do totemizma on tumači savezom braće radi oceumorstva. Naime, on pretpostavlja, slijedeći Robertsona Smitha i Darwina, da su u prirodnom stanju prevladavale manje obiteljske zajednice mužjaka i njegovih ženki. Kada muški potomci dosegnu spolnu zrelost, dolazi do borbe za vlast te se najjači, najče-

Moderni subjektivizam svoj filozofski izričaj dobiva u egzistencijalnoj filozofiji koja razmatra mogućnosti samoodređenja jastva unutar institucionalno i običajno postavljenoga okvira. Heidegger u Bitku i vremenu postavlja pravosti egzistencije tubitka kao određenje vlastitih mogućnosti nakon što je stavljena $u$ zagradu cjelina određenja mogućnosti koju nameće javno mnijenje, ono »Se«. Istu problematiku iznosi i Sartre u Bitku i ništa izlažući razlikovanje između bitka za sebe i bitka za druge (usp. Heidegger, 1967: 167-180; Sartre, 2008: 401-434).

10

Teoretičari društvenog ugovora Hobbes i Rousseau iznose suprotstavljena viđenja prirodnog stanja. Hobbes u Levijatanu, poput Freuda, polazi od pretpostavke da je prirodno stanje »rat svakoga protiv sviju« te da pojedinac koji je po prirodi zao i sebičan ograničava vlastitu slobodu društvenim ugovorom da bi izbjegao neprestanu opasnost od pogibelji. Za razliku od njega, Rousseau vjeruje da je čovjek plemeniti divljak, da prirodno stanje pruža idilično opstojanje te da je idila narušena nastankom privatnog vlasništva. Čovjek je iskonski dobar, a društvo ga svojim institucijama, staležima i privatnim vlasništvom nagoni na nečasno djelovanje (usp. Hobbes, 2004: 90-114; Rousseau, 1978: 29-51). 
šće najstariji mužjak nameće kao vođa, a ostali su ili ubijeni ili protjerani. $\mathrm{Na}$ taj način najjači mužjak onemogućava seksualni promiskuitet unutar obitelji te nameće normu egzogamije mlađim mužjacima (usp. Freud, 1961: 153).

Protjerana braća oceumorstvom prekidaju očevu hordu jer im je međusobni savez dao snagu da učine ono što je svakome ponaosob bilo nezamislivo zbog ambivalentnih osjećaja prema ocu. Budući da prema ocu prevladavaju ambivalentni osjećaji, umorstvom su zadovoljili mržnju, proždiranjem zaklanog oca poistovjećenje s njegovim idealom koji štuju te nakon čina preostaju nježni osjećaji. Nježni osjećaji pokazuju se u opozivu čina umorstva zabranom ubijanja očeva zamjenskoga objekta - totema - te u tome što se odriču plodova svog zločinačkog podviga - putenog uživanja u očevim ženama. Otac postaje totem, a kopulacija s ženskim pripadnicama svog totema - tabu. Dakle, oni si sada sami brane ono što im je branio živi otac, a ta zabrana incesta dugoročno je plodonosna za opstanak njihova saveza i zajednice jer eliminira trvenja oko zadovoljenja seksualnih potreba. Poistovjećenje oca $\mathrm{s}$ totemom ugovor je s ocem u kojem on pristaje biti zaštitnik, čime se ostvaruje imaginarno infantilno očekivanja sinova od očinske figure. Ne samo da je ugovor nego savezom s totemom sinovi ujedno pokušavaju opravdati svoj zločinački čin tvrdeći da ni oca ne bi ubili da je bio zaštitnik, a ne zli nasilnik (usp. Freud, 1961: 172-175).

Kao znak sjećanja na svoj zločinački čin sinovi ponavljaju obred totemskog objeda. Totemski objed žrtveni je obred plemenskih srodnika u kojem konzumiraju totem. Klanje totema dopušteno je samo u slučaju žrtvenog objeda kod kojeg svi članovi plemena sudjeluju u klanju i objedovanju. Tako, sukladno savezu braće zbog oceumorstva, kolektivno im je dozvoljeno ono što je zabranjeno svakom pojedincu. Nakon objeda žaluje se ubijena životinja, no žalopojka je egoistično licemjerna jer je motivirana strahom od odmazde te smjera prema neutralizaciji odgovornosti. Žalovanje je okončano ekscesivnom zabavom u kojoj se oslobađaju svi nagoni i dopuštaju njihova zadovoljenja. Značaj totemskog objeda za plemensku zajednicu ponovna je potkrjepa zajedništva da se članovi prisjete da trebaju solidarno nastupati jedan za drugog jer ih krvno srodstvo čini povezanima u jednu jedinku (usp. Freud, 1961: 164-166). Na temelju izloženog možemo zaključiti da je totemistička kultura utemeljena na ograničenjima koja članovi plemena nameću jedni drugima radi održanja novog poretka.

»Totemizam je i religiozni, kao i društveni sustav. Po svojoj religioznoj strani on postoji u povezivanju te uzajamnom poštovanju i čuvanju između čovjeka i njegovog totema, dok se po svojoj socijalnoj strani očituje u međusobnim obvezama članova klana jednih prema drugima i svih prema drugim plemenima [...] braća i sestre koji se moraju međusobno štititi [...] žele istaknuti sličnost spram totema.« (Freud, 1961: 126-127)

Tabu propisi koji baštine svoje podrijetlo od vjerovanja u demonsku silu čine jezgru novog zakona totemskog društva. Odnos spram demonskog određen je ambivalencijom u kojoj se prožima strahopoštovanje i gnušanje jer demon raspolaže neizmjernom snagom kojoj se treba diviti, ali i strahovati pred njom jer demon sankcionira dodirivanje ili nedopušteno korištenje zabranjenog. Zabranjeno tabuom uvijek je ono najželjenije jer ne bi postojala potreba za tako radikalnom demonskom odmazdom kada ne bi postojala nesavladiva želja. Kada izostane demonska kazna, pripadnici plemena kažnjavaju prijestupnika jer samo se tako može eliminirati iskušenje spram ponovnog zadovoljenja tabuom zabranjene želje kod ostalih pripadnika plemena. Temeljni su tabui totemističkih plemena zabrana incesta i zabrana ubijanja totema. Takve tabue 
treba strogo razlikovati od religioznih i moralni zabrana: religiozne zabrane nastaju na temelju zapovjedi božanstva, ${ }^{11}$ a moralne su ishod sustava moralnih uvjerenja. Za razliku od njih, zabrane su tabua misteriozne, njihovo podrijetlo ostaje nerazjašnjeno, zabrana racionalno neobrazloživa i jasna samo onima koji su pod vlašću tabua (usp. Freud, 1961: 33-34, 86-89).

Već u prvom obliku društvenog uređenja jasno se pokazuje tendencija kulture da ograniči nagonska zadovoljenja svojih članova.

»Prva faza kulture, totemizam, već nameće zabranu incestuoznog izbora objekta, što je možda najteže sakaćenje koje je ikad pretrpio čovječji ljubavni život. Tabu, zakoni i običaji postavljaju nova ograničenja koja pogađaju i muškarce i žene.« (Freud, 1955: 463)

Freud priznaje da je nužno određeno ograničenje nagona, posebice agresivnih nagona $^{12}$ jer čovjeku bližnji ne predstavlja samo pomoćnika pri radu i seksualni objekt nego i objekt njegovih agresivnih stremljenja. Agresija se može manifestirati od podjarmljivanja tuđe slobode, preko iskorištavanja tuđeg rada i prisvajanja imovine, do fizičkog i seksualnog zlostavljanja. Sprječavanje iskazivanja agresije prema drugom dovodi do suviše velike internalizacije agresije protiv vlastitoga Ja. Nažalost, kultura ne inzistira samo na ograničenju agresivnih sklonosti nego je primarno usmjerena na ograničavanje seksualnog nagona, kao što se može vidjeti već u totemističkom zahtjevu za egzogamijom. Totemistička je egzogamija učinkovitija od jednostavne zabrane incesta jer izjednačava sve pripadnike istog totema sa srodnicima te time priječi izbor većeg broja libidoznih objekata (Freud, 1961: 20).

Razvojem kulture raste i stupanj odricanja koja se očekuju od čovjeka te u građanskom društvu početkom dvadesetog stoljeća Freud dijagnosticira da čovjek postaje neurotičan jer ne može podnijeti stupanj odricanja koji od njega zahtijeva kultura. Kultura se ponovno primarno usmjerava na potiskivanje seksualnog nagona pomoću civilizirane seksualne moralnosti. Unutar civilizacijske progresije Freud detektira tri stadija seksualne represije: u prvom se seksualni nagon mogao slobodno zadovoljavati, u drugom je pak ograničen na genitalnost sa suprotnim spolom koja služi prokreaciji, a u trećem je dopuštena samo prokreacija unutar bračne veze. Već drugi stadij onemogućava zadovoljenje velikom broju članova društva koji su usmjereni na druge erogene zone (npr. oralno, analno) ili seksualne objekte (npr. homoseksualnost, fetišizam) koje društvo osuđuje kao perverzno. Daljnja represija nastupa $\mathrm{s}$ moralnim osuđivanjem svake seksualne aktivnosti koja nije vezana uz monogamnu heteroseksualnu zakonsku zajednicu ${ }^{13}$ (usp. Freud, 1951: 152).

11

Svoja izlaganja o religiji Freud iznosi u djelima Mojsije i monoteizam te Budućnost jedne iluzije (Freud, 1955; Freud, 1962).

12

Postojanje agresivnih nagona Freud objašnjava svojom drugom teorijom nagona unutar koje razlikuje nagon života - Eros - i nagon smrti - Thanatos. Ono što razlikuje Eros i Thanatos od prve teorije nagona koja postavlja libido i nagon samoodržanja kao temeljne nagone jest to što Eros i Thanatos Freud razumijeva kao ontološke principe. Eros je zaslužan za sve oblike spajanja u veće cjeline $\mathrm{i}$ rasta u prirodi, a Thanatos za sve oblike propadanja u smislu svođenja organskog na anorgansko stanje. Eros se kod čovjeka očituje kao tendencija k očuvanju života te ujedinjuje nagon samoodržanja koji je zaslužan za vlastiti opstanak i libido koji je zaslužan za opstanak vrste. Thanatos se kod čovjeka manifestira kao agresivne tendencije, nagon za moći i razaranjem (usp. Freud, 1967a: 3-69).

13

Marcuse sintagmom »višak potiskivanja« želi označiti dodatne kontrole koje uvode specifične ustanove, a koje se primarno odnose na modifikacije i skretanja nagonske energije prouzrokovane održavanjem monogamno-patrijarhalne obitelji. Njima uvjetovano ujedinjavanje spolnih nagona i podvrgavanje 
Razlozi za civilizacijsku represiju seksualnog nagona nisu ni nužni ni očigledni. Slobodno zadovoljavanje seksualnog nagona ne dovodi u pitanje opstanak u zajednici kao što je slučaj kod agresivnih nagona. Čak ni zabrana incesta nema biološko utemeljenje jer bi prirodni odabir eliminirao bilo kakve malformacije nastale križanjem bliskih krvnih srodnika kao što to čini i kod ostalih životinjskih vrsta. Stvara se dojam da civilizacija hotimično otežava zadovoljenje seksualnog nagona postavljajući niz neopravdanih zapreka seksualnom zadovoljenju. To čovjeku predstavlja posebno velik problem jer je njegov seksualni nagon jači i trajniji nego kod ostalih životinjskih vrsta, čija je prokreacija vezana uz strogo određene periode parenja. Taj civilizacijski fenomen Freud tumači upotrebom energije seksualnog nagona za postizanje kulturnih ciljeva, čime kultura zahtijeva odricanja koja nadilaze njezinu funkciju zaštite. Povećavajući obim ljudskih odricanja, kultura preusmjerava energiju spolnog nagona na ostvarenje kulturnih dostignuća i ideala koji nisu izravno povezani s ljudskom dobrobiti. Sposobnost deseksualizacije spolnog nagona posljedica je plastičnosti nagona - mogućnosti nagona da ne mijenja samo svoj objekt već i cilj. ${ }^{14}$ Promjena cilja nagona očituje se kroz nadoknađivanje zadovoljenja jednog nagona zadovoljenjem drugog ili sublimiranjem. Sublimiranje je proces u kojem je nagon preusmjeren na novi neseksualni cilj koji se pozitivno društveno vrednuje. U užem smislu, pod aktivnostima sublimiranja podrazumijeva umjetničko djelovanje i intelektualno istraživanje. Freud ističe da sublimacija nije proces koji je intrinzičan čovjeku, već je posljedica kulturalnog ograničavanja nagonskog zadovoljenja. Kultura ograničava nagon da bi osigurala opstanak poretka i vlastiti prosperitet (usp. Freud, 1951: 150).

»Sublimacija nagona je posebno istaknuta crta kulturnog razvitka, ona omogućava da više psihičke aktivnosti, znanstvene, umjetničke, ideološke, postignu tako značajnu ulogu u kulturnom životu. Prepuštajući se prvom utisku, moglo bi se reći da je sublimacija uopće sudbina nagona, iznuđena kulturom.« (Freud, 1955: 457)

Problem nastaje jer je energetska kvantiteta nagona dostupna za sublimaciju individualno varijabilna; od osobe do osobe varira i jačina seksualnog nagona i kvantiteta koja može biti sublimirana. Kvantiteta dostupna za sublimaciju ${ }^{15}$ ne može se širiti do totaliteta jer svaki pojedinac zahtijeva stanovitu kvantitetu spolnog zadovoljenja. Freud zaključuje da se, ukoliko bude dodatno raslo kulturalno ograničavanje spolnog nagona, utoliko može očekivati hipertrofija neurotičnih oboljenja.

Kultura ostvaruje takvo ograničenje ljudskog zadovoljenja nagona kroz introjekciju moralnih normi i civilizacijskih običaja. Naime, Freud smatra da čovjeka karakterizira trodijelni ustroj psihe, ${ }^{16}$ a jedan od tri dijela je i Nad-ja u koji je smještena moralna i običajna zakonodavnost. Nastanak Nad-ja veže se uz poistovjećivanje s instancijom roditelja koja čini jezgru njihovih moralnih $\mathrm{i}$ običajnih vrijednosti. Dakle, poistovjećuje se s roditeljskim Nad-ja, a ne s njihovom osobnošću. Poistovjećivanjem djetetov Nad-ja postaje nositelj tradicijskih normi i vrijednosnih sudova kojima se u njega impregniraju i kulturom postavljena ograničenja seksualnog nagona. Nad-ja u sebi nosi prohibitivnu funkciju savjesti koja nadzire i procjenjuje činove Ja i regulatornu funkciju pounutrenog ideala, autoriteta prema kojem savjest procjenjuje djelovanje Ja. Savjest u sebe preuzima agresivne nagone čije zadovoljenje priječi kultura, preciznije agresivne nagone spram roditeljskog autoriteta. Kroz takvu internalizaciju, agresivni nagon ${ }^{17}$ koji se trebao zadovoljiti na drugome okreće se protiv vlastitoga Ja. Rad savjesti dovodi do nastanka osjećaja krivnje kod Ja 
bez obzira je li zabranjeni čin sproveden ili je samo fantazija i misao budući da je autoritet internaliziran te se od njega zabranjene želje ne mogu sakriti. Dakle, ograničenje zadovoljenja nagona nametnuto izvanjskim autoritetom stvara savjest kao internaliziranu formu koja zahtijeva još strožu kontrolu zadovoljenja nagona (usp. Freud, 1965: 256-267; Freud, 1955: 482-493).

»... što god je čovjek čestitiji, utoliko se strože i nepovjerljivije ponaša savjest. Vrhunac dostiže u svetaca, koji sebe optužuju zbog najtežih grijeha. Vrlina pri tome gubi dio obećane nagrade, poslušno i asketsko Ja ne uživa povjerenje svoga mentora, trudi se, čini se uzalud, da ga stekne.« (Freud, 1955: 484)

Nametanjem moralnosti i ograničenjem spolnog zadovoljenja ne iscrpljuju se modusi kulturom uvjetovanog ograničenja ljudske slobode. Kultura intervenira i u uspostavljanja objekta nagona, preciznije ono željeno predodređeno je kulturom. To je moguće jer ljudski objekt zadovoljenja nagona nije vrsno predeterminiran kao kod ostatka živog svijeta, već je individualan i uvjetovan infantilnom poviješću pojedinca. Za čovjeka, objekt nagona uspostavlja se u činu pradoživljaja zadovoljenja u kojem izvanjska intervencija majke zadovoljava podražaj. Slika objekta prvog zadovoljenja postaje predložak za zasnivanje želje pojedinca. To znači da kada naredni put izvor nagona producira podražaj, pojedinac će žudjeti za specifičnim objektom zadovoljenja nagona. Nužnost posredovanja slike objekta prvobitnog zadovoljenja prilikom uspostave objekta nagona proizlazi iz same prirode nagona. Budući da je nagon granični pojam između somatskog i psihičkog, a somatsko se po sebi ne može se izraziti u psihičkome, nagon je u psihičkom predstavljen pomoću predodžbenog reprezentanta. Predodžba je u psihi zapisani trag sjećanja objekta prethodnog zadovoljenja nagona. Pritom je važno napomenuti da pojedinac ne mora nužno replicirati puteve prvobitnog zadovoljenja, već raspolaže fleksibilnošću nagonskog zadovoljenja. Navedeno znači da je kroz život pojedinca

prokreativnoj funkciji mijenja prirodu spolnosti koja od autonomnog načela postizanja općeg užitka na određenim erogenim zonama postaje specijalizirana privremena funkcija sredstva za cilj - reprodukcije (usp. Marcuse, 1974: 37-39)

14

Po Freudovu mišljenju, nagon je određen pomoću tri parametra: izvora nagona somatskog momenta koji je ishodište podražaja, objekta - onoga na čemu nagon postiže zadovoljenje, koji je uvjetovan infantilnom poviješću pojedinca, i cilja - aktivnosti na koju nagoni nagon i koja vodi do zadovoljenja (usp. Freud, 1946a: 210-232)

15

U Čovjeku jedne dimenzije, Marcuse razvija pojam desublimacija, pomoću kojega želi obuhvatiti fenomen oslobađanja agresivnosti i seksualnosti u kasnom kapitalizmu. Pomoću kontrolirane desublimacije koja oslobađa potisnute seksualne i agresivne nagone represivna društvena moć postaje moć koja stvara univerzum zadovoljenja i time slabi instinktivni revolt protiv zbiljnosti (usp. Marcuse, 1964: 59-87)
16

Freud je u svojoj teoriji razvio dvije topike. Prva topika psihički aparat dijeli na tri dijela: svijest, predsvjesno i nesvjesno. Funkcija je svijesti primanje podražaja iz vanjskog svijeta, predsvjesno obuhvaća neaktualizirana znanja i sjećanja, a nesvjesno predodžbene reprezentante uređene $\mathrm{u}$ imaginarne scenarije. Iako druga topika ima niz dodirnih točaka s prvom, nije joj analogna. »Ja« iz druge topike ujedinjuje sustave predsvjesnog i svijesti iz prve, »Ono« u sebi sadrži nesvjesne i potisnute predodžbe, dok »Nad-Ja« uvodi novu dimenziju običajnosti i morala u psihički aparat (usp. Freud, 1946c: 264-303; Freud, 1967b: 237-289).

17

O destruktivnosti »Nad-ja« govori i Ricœur. Za njega »Nad-ja« nije samo nabijen libidalnim ostatcima preko njegova nastanka u razrješenju Edipova kompleksa nego i destruktivnim bijesom Thanatosa. Nagon smrti u »Nad-ja« manifestira se kao »strahovlada ponižavajuće moralne svijesti« koja kao da nema drugog izbora osim mučiti sebe ili druge svojom agresivnošću (usp. Ricœur, 2005: 294). 
prvobitni objekt zadovoljenja nagona najčešće zamijenjen drugim objektima koji su dostupni pojedincu kao tragovi sjećanja. Prostor za kulturnu manipulaciju objektom ljudske želje otvara fiziološka nevezanost želje i objekta njezina zadovoljenja. Kultura vežući objekte želje uz autoritete koji su introjicirani kao ideali i tako nagoni želju pojedinca u kulturno prihvatljivom smjeru. Čovjek počinje željeti nametnute objekte te u procesu njihova osvajanja doprinosi izgradnji kulture. To ne bi nužno imalo negativni vrijednosni predznak kada navedeno djelovanje ne bi od čovjeka zahtijevalo potiskivanje i sublimaciju seksualnog nagona te time osujetilo njegovu seksualnu slobodu. Kulturalno je podrivanje seksualne slobode u temelju nezdravo jer vodi čovjeka u neurozu (usp. Freud, 1946c: 275-279; Freud, 1946b: 250-256).

\section{Zaključak}

Usporedba Freudeova i Gehlenova određenja čovjeka ukazuje na njegovu slobodu od nagona unutar kulture i civilizacije. Gehlen apostrofira ljudsku sposobnost kočenja nagona koja je nužna za ljudski opstanak jer čovjek mora dalekosežno planirati zadovoljenje svojih nagona. Freud smatra da je čovjek nagonsko biće, no sposobnost sublimacije i potiskivanja omogućava mu da odgodi svoje zadovoljenje nagona u skladu sa zahtjevima zbiljnosti. Obojica smatraju da sloboda od nagona uvjetuje nepostojanje vrsno zadane reakciju na potrebite predmete iz svog staništa. Umjesto toga, čovjek nema određeno stanište, a objekt želje ili potrebe uspostavlja na temelju slika iskustva. Gehlen smatra da je nagonska nevezanost čovjeku u podjednakoj mjeri prednost i opterećenje jer manjak instinktivnog automatizma reakcije zahtijeva neprestano donošenje odluka pri djelovanju. Čovjek nadilazi taj problem navikom koja uspostavlja drugostupanjski automatizam instinktivnog te tako stabilizira djelovanje. Institucije putem društvenog odgoja implementiraju obrasce stabilnih ponašanja, $u$ čemu Gehlen vidi pozitivnu paradigmu koja rasterećuje svakodnevno djelovanje. Freud, s druge strane, u institucionalnim intervencijama vidi bespotrebna ograničenja ljudske slobode koja generiraju novu vrstu neslobode. On priznaje da je unutar kulture nužno stanovito ograničenje agresivnih nagona, no smatra da je kulturna represija seksualnog nagona potpuno bespotrebna. Ona postaje posebno problematična u građanskom društvu na početku dvadesetog stoljeća jer obim odricanja koja traži kultura nadilazi ljudske mogućnosti potiskivanja i sublimacije te vodi pojedinca $u$ neurozu. Suvremena kultura ostavlja dojam permisivnosti u odnosu na zadovoljenje agresivnih i seksualnih nagona. Permisivnost ostaje iluzorna jer se mijenja samo taktika kontrole. Kultura nameće objekte želje pojedincu te on, misleći da zadovoljava vlastite želje, radi za kulturne svrhe. Nesvršivi rad na zadovoljenju kulturno uspostavljenih želja vodi k permanentnom odgađanju zadovoljenja.

\section{Literatura}

Bošnjak, Branko (1993): Povijest filozofije, sv. III, Nakladni zavod Matice hrvatske, Zagreb.

Descartes, René (1993): Razmišljanja o prvoj filozofiji, prev. Tomislav Ladan, Demetra, Zagreb.

Cassirer, Ernst (1980): The Philosophy of Symbolic Forms, prev. Ralph Manheim, Yale University Press, New Haven. 
Freud, Sigmund (1946a): »Triebe und Triebschicksale«, u: Freud, Sigmund: Gesammelte Werke, sv. 10, Werke aus den Jahren 1913-1917, S. Fischer Verlag, Frankfurt na Majni, str. 210-234

Freud, Sigmund (1946b): »Die Verdrängung«, u: Freud, Sigmund: Gesammelte Werke, sv. 10, Werke aus den Jahren 1913-1917, S. Fischer Verlag, Frankfurt na Majni, str. 248-264.

Freud, Sigmund (1946c): »Das Unbewußte«, u: Freud, Sigmund: Gesammelte Werke, sv. 10, Werke aus den Jahren 1913-1917, S. Fischer Verlag, Frankfurt na Majni, str. 264-306.

Freud, Sigmund (1951): »Die 'kulturelle' Sexualmoral und die moderne Nervosität«, u: Freud, Sigmund: Gesammelte Werke, sv. 7, Werke aus den Jahren 1906-1909, S. Fischer Verlag, Frankfurt na Majni, str. 143-171.

Freud, Sigmund (1955): »Das Unbehagen in der Kultur«, u: Freud, Sigmund: Gesammelte Werke, sv. 14, Werke aus den Jahren 1925-1931, S. Fischer Verlag, Frankfurt na Majni, str. 419-507.

Freud, Sigmund (1961): Totem und Tabu. Einige Übereinstimmungen im Seelenleben der Wilden und der Neurotiker, u: Freud, Sigmund: Gesammelte Werke, sv. 9, Totem und Tabu. Einige Übereinstimmungen im Seelenleben der Wilden und der Neurotiker, S. Fischer Verlag, Frankfurt na Majni.

Freud, Sigmund (1962): »Der Mann Moses und die monotheistische Religion«, u: Freud, Sigmund: Gesammelte Werke, sv. 16, Werke aus den Jahren 1932-1939, S. Fischer Verlag, Frankfurt na Majni, str. 101-249.

Freud, Sigmund (1967a): »Jenseits des Lustprinzips«, u: Freud, Sigmund: Gesammelte Werke, sv. 13, Jenseits des Lustprinzips / Massenpsychologie und Ich-Analyse / Das Ich und das Es Und andere Werke aus den Jahren 1920-1924, S. Fischer Verlag, Frankfurt na Majni, str. 1-71.

Freud, Sigmund (1967b): »Das Ich und das Es«, u: Freud, Sigmund: Gesammelte Werke, sv. 13, Jenseits des Lustprinzips / Massenpsychologie und Ich-Analyse / Das Ich und das Es Und andere Werke aus den Jahren 1920-1924, S. Fischer Verlag, Frankfurt na Majni, str. 235-291.

Gehlen, Arnold, (1978), Der Mensch: Seine Natur und seine Stellung in der Welt, Akademische Verlagsgesellschaft Athenaion, Wiesbaden.

Gehlen, Arnold (1994): Čovjek i institucije, prev. Kiril Miladinov, Nakladni zavod Globus, Zagreb.

Heidegger, Martin (1967): Sein und Zeit, Max Niemeyer Verlag, Tübingen.

Hobbes, Thomas (2004): Levijatan, prev. Borislav Mikulić, Naklada Jesenski i Turk, Zagreb.

Kant, Immanuel (1956): Kritik der reinen Vernunft, Felix Meiner Verlag, Hamburg.

Kant, Immanuel (1963): Kritik der Urteilskraft, Verlag Phillip Reclam, Stuttgart.

Kant, Immanuel (1989): Kritik der praktischen Vernunft, Verlag Phillip Reclam, Stuttgart.

Lévi-Strauss, Claude (1969): The Elementary Structures of Kinship, prev. James Harle Bell, John Richard von Sturmer, Rodney Needham, Beacon Press, Boston.

Marcuse, Herbert (1964): One-Dimensional Man: Studies in the Ideology of Advanced Industrial Society, Routledge \& Kegan Paul Ltd., London.

Marcuse, Hebert (1974): Eros and Civilization, Beacon Press, Boston.

Plessner, Helmuth (1985): Gesammelte Schriften IX: Schriften zur Philosophie, Suhrkamp Verlag, Frankfurt na Majni.

Plessner, Helmuth (1994): Condicio humana: filozofijske rasprave o antropologiji, prev. Branko Despot, Globus, Zagreb.

Ricœur, Paul (2005): O tumačenju: ogled o Freudu, prev. Ljiljanka Lovrinčević, Ceres, Zagreb.

Rousseau, Jean-Jacques (1978): Rasprava o porijeklu i osnovama nejednakosti među 
ljudima; Društveni ugovor, prev. Dalibor Foretić, Školska knjiga, Zagreb.

Sartre, Jean-Paul (2008): Being and Nothingness. An Essay on Phenomenological Ontology, prev. Hazel E. Barnes, Routlege, London.

Scheler, Max (1991): Die Stellung des Menschen im Kosmos, Bouvier, Bonn.

Saunders, Barbara (2006): Ivan Pavlov: Exploring the Mysteries of Behavior, Enslow Publishers, Berkeley Hights.

\title{
Martina Volarić
}

\section{Unfreedom of Freedom}

\begin{abstract}
The paper aims to examine the extent of individual freedom of human being in relation to their instinctual bodily attachment. The starting point of examination is Gehlen's biological anthropology which pointed to human freedom of instinctual pressures. Human freedom proves to be an opportunity to build one's world through action. Freedom of action burdens human beings with constant decision-making. The automatism of habit, which provides solid patterns of unconscious behaviours, allows relief from freedom of action. By their upbringing, social institutions additionally automate and thus stabilise individuals'actions. In their world produced from freedom, human beings generate a second-degree, self-produced non-freedom. Freud points to the oppressive character of culture and civilisation, which requires the individual to sacrifice instinctual gratification for the sake of cultural prosperity. As instinctual repression grows with the development of culture, the modern human being becomes neurotic because they cannot tolerate the degree of renunciation that culture demands of them.
\end{abstract}

\section{Keywords}

Arnold Gehlen, Sigmund Freud, sublimation, relief 